\title{
Emergence and Scale-up of Frugal Innovations: The Relevance of University-Industry Interaction
}

\author{
Darío Reyes Reina ${ }^{1}$ Ariane Agnes Corradi², Márcia Siqueira Rapini ${ }^{3 *}$
}

\begin{abstract}
This article analyses the emergence and scale-up of frugal innovations supported by university-industry interactions in the Colombian context. We conducted semi-structured interviews with eight researchers from the National University of Colombia, who participated in activities to transfer technology to society through frugal innovations. Results highlight the social role of the Colombian university and the motivations of the participating researchers to develop frugal innovations. Three benefits of the university-industry interaction to develop and upscale frugal innovations were identified and described: a) the exchange of specialised knowledge that helps to do incremental improvements on frugal innovations; b) the strengthening of distribution and marketing strategies of innovation, supporting its implementation in different contexts; and c) advantages in scaling up production. The relevance of these findings to understand frugal innovation processes and their implications for designing support services by university technology transfer offices are discussed.
\end{abstract}

Keywords: frugal innovation; Scale-up; university-industry interaction; Interaction Channels; Colombia

Submitted: May $28^{\text {th }}, 2021 /$ Approved: October $26^{\text {th }}, 2021$

\section{Introduction}

Frugal innovations have aroused great interest in recent years as an alternative for sustainable and social development in both emerging and economically developed countries. In spite of several definitions for the concept, we adopted the one based on measurable criteria: frugal innovations simultaneously fulfil three interrelated main characteristics: 'substantial cost reduction, concentration on core functionalities, and optimised performance level' (Weyrauch \& Herstatt, 2017, p. 12).

Although there is growing literature about frugal innovation, there are still many unanswered questions. One major gap is related with examining the process that leads to frugal innovation outcomes (Koerich \& Cancellier, 2019); another is the necessity of a deeper understanding about diffusion and commercialisation of frugal innovations (Hossain et al., 2016; Pisoni et al., 2018). It is often argued that synergies between different actors as local communities, government, non-governmental organisations, universities and industry helps innovation emergence and diffusion, but it is still opaque how these partnerships are made and what characteristics they have.

Particularly, this study analyses the emergence and scale-up of frugal innovations supported by university-industry (U-I) interactions in the Colombian context. The article is organised as follows. First, a deeper analysis is made on the concept of frugal innovation and the relevance of the theoretical framework of U-I interaction channels in understanding the partnerships that drive frugal innovation. Second, the qualitative methodology that guided the study and some general characteristics of the National University of Colombia are described.
Third, the results of the research are presented, beginning with a contextualization about the social role of universities and the motivations of the researchers to develop frugal innovations. Then, three benefits of the U-I interaction in the development of frugal innovations are exposed. To conclude, the discussion and final considerations are presented, exploring the relevance of U-I interaction in reducing bottlenecks in the frugal innovation process and their potential implications for university technology transfer offices.

\section{Literature Review}

\section{Frugal Innovation}

Frugal innovation has gained greater attention in recent years, currently representing an open debate about its boundaries and main characteristics. Recent articles of theoretical reflection and literature review (Hossain, 2018; Soni \& Krishnan, 2014; Weyrauch \& Herstatt, 2017) have attempted to understand what might be considered frugal innovation and what the overlaps with and differences from other concepts are, such as social innovation. Here, given the prevalent adoption of the social innovation discourse in the Colombian context, explained by developing countries' need to focus on social problems rather than focussing on cutting-edge technology (Van der Have \& Rubalcaca, 2016), the next subsection explores some overlaps and differences between the two concepts.

Distinguishing Frugal Innovation from Social Innovation. The literature on social innovation acknowledges that this field of studies precedes that of technological innovation for its interest in the structural transformations of society and its social relations for over 200 years. Despite early works applying the term 'social

(1) Post-graduation programme in Technological Innovation, Federal University of Minas Gerais, Belo Horizonte, Brazil

(2) Psychology department, Federal University of Minas Gerais, Belo Horizonte, Brazil

(3) Center for Development and Regional Planning (CEDEPLAR), Federal University of Minas Gerais, Belo Horizonte, Brazil

*Corresponding author: msrapini@cedeplar.ufmg.br 
innovation' dating back to the beginning of the twentieth century, it is only around the 1960s-1970s that the field (re-)emerged as such, with strong social movements around ecology, feminism, and civil rights (Edwards-Schachter \& Wallace, 2017). Nevertheless, social innovation has been overlooked by the majority of innovation literature, which have focused on technological innovation in manufacturing (Van der Have \& Rubalcaba, 2016), or, alternatively, was delegated a subsidiary role or viewed as an inductor of technological innovation (Edwards-Schachter \& Wallace, 2017).

Literature reviews on social innovation describe its evolution and clustering, which, in turn, allow examining the relationships between social innovations and the newly coined concept of frugal innovations. Edwards-Schachter and Wallace (2017) showed that:

During the first decades SI was conceived as a process developed by and oriented to the third sector, not based on technological knowledge or $\mathrm{R} \& \mathrm{D}$, and differentiated from institutionalized social practices and social inventions (a programme, a model, a standard, a norm, a procedure) arising from technology-based innovations. But progressively (and particularly due the impact of the knowledge society) SI was used to name the development of products, processes and services mediated by technologies or closely linked to technological innovations with social purposes (i.e., with the explicit objective to produce benefits in terms of social impact). Other characteristic is the growth observed in SI as hybrid collaborative innovation between the third sector, the public sector and/or business actors (Edwards-Schachter and Wallace, 2017, p. 74).

Out of the three clusters in the social innovation literature identified by Edwards-Schachter and Wallace (2017), two of them could incorporate the concept of frugal innovation: (sustainable) development, which includes technological innovation and new products, and services sector, which includes addressing social needs by linking market and society. However, the distinctive participation of non-governmental organisations, social movements and social entrepreneurs in changing social practices and social values in the social innovation process, may impose a conceptual distance between the concepts of social innovation and frugal innovation. The lack of focus in social innovation on doing more with less resources, which is paramount in frugal innovation, is another critical distinguishing factor.

The literature review of social innovation by Van der Have and Rubalcaca (2016) identified four clusters in this field: creativity research, community psychology, local development, and social and societal challenges. Frugal innovation is relatable with the latter cluster, as it refers to innovative solutions to socio-technical challenges or social problems, sustainability, grassroots innovations, and cross-sector partnerships. As social innovation studies in this cluster focus on outcomes and specific solutions with higher economic content rather than social processes, it allows approximations to frugal innovation studies.

In sum, there is convergence between the concepts of frugal innovation and social innovation in relation to their aims, purposes, and expected outcomes, which are oriented toward attending unmet social needs to improve the quality of life of innovation users, represented mostly by marginalised people and communities. Nevertheless, there can be divergence between these concepts in relation to the processes involved (bottom-up social practices vs. R\&D, unplanned vs. planned, relevant actors involved, innovation locus, sources of ideas and resources, the relationship between social and technological systems, and organisation and governance). Therefore, we consider that these two concepts are not synonymous, although, under certain circumstances, frugal innovations can also be considered as social innovations. These circumstances include providing responses to social demands that might not be commercially viable and developing products and services through a combination of private, public and third sectors (Van der Have \& Rubalcaca, 2016). On a caution note, these convergences and distinctions might need revisiting for other definitions of frugal innovation (i.e., Bhatti \& Ventresca, 2013).

Defining Frugal Innovation. Frugal innovation could be defined by simultaneously fulfilling three interrelated main characteristics: 'substantial cost reduction, concentration on core functionalities, and optimised performance level' (Weyrauch \& Herstatt, 2017, p. 12). Substantial cost reduction means solutions that are cheaper than previous ones, but not necessarily inexpensive. Historically, frugal innovation has been linked to products and services for people with low incomes or the so-called 'base of the pyramid', but new approaches argue that this frugal principle also applies in economically developed countries or large companies that want to do 'more with less' (Koerich \& Cancellier, 2019; Tiwari et al., 2016), or 'better with less' (Radjou \& Prabhu, 2019).

The focus on core functionalities and optimised performance level is related to the explicit purpose of creating a 'good enough' solution to a problem (Soni \& Krishnan, 2014), maintaining a fit between quality, performance, and the specific requirements in a local context (Weyrauch \& Herstatt, 2017). In many circumstances this means avoiding unnecessary features that raise the cost of production and could create financial barriers to adoption.

Most of the studies about frugal innovation came from India, disclosing a knowledge gap about this kind of innovation in other regions of the world (Hossain, 2017). In Latin America, the concept of frugal innovation is relatively new. For instance, it was only in 2019 that the Latin American Network of Frugal Innovation was created, associating universities with the purpose of promoting this type of innovation in the region (Red Latinoamericana de Innovación Frugal, 2020). However, there are few documented cases. In Brazil, a study analysed two cases of solar energy technology targeting an underserved market of low-income families (Busch et al., 2018), using the framework of Soni and Krishnan (2014), which divides frugal innovation into mindset, process, and outcome. An interesting result of Busch et al. (2018) was the identification of the intention of frugal innovations creators to generate a social impact on vulnerable populations, while strengthening sustainability and circular economy, as a central element to explain the emergence of these innovations. In Ecuador, Pansera (2017) describes four cases of frugal innovation, an irrigation system for small farmers, 
ecological toilets with recycled material, organic waste for composting and an optimisation system for cocoa production in rural areas. The author argues that the emergence of innovations is explained by a combination of elements in which an orientation to solve local problems and the creation of synergies between traditional knowledge and personal inventiveness stood out (Pansera, 2017).

In the health area, the literature reports experiences from three countries. In Colombia, there is a case about $3 \mathrm{~d}$ printing of cardiac structures with the objective of making health services more accessible to the population at the base of the pyramid (Arias et al., 2015). In Uruguay, Bianchi et al. (2017) describes two frugal innovations, a Neuronavigator and a Human milk pasteurizer. They tackle unmet health needs and stand out because they became viable through interactions between several actors with diverse capacities, such as a public hospital with researchers from a university in the first case, and the same hospital with a small food company in the second case. Finally, in Mexico Bayardo et al. (2018) analyse a low-cost health service called 'farmacy - doctor model', a frugal innovation that arises as a response to a gap in the market, creating a new model that would allow access to health services in an economic way, marketing generic drugs and offering short consultations with health professionals at low cost.

Summarizing, most of the evidence on frugal innovation in Latin America is about case studies in the area of health, agriculture and access to public services. Furthermore, although some studies mention the importance of synergy between different actors (industry, universities, communities) for the emergence and diffusion of frugal innovations (Bayardo et al., 2018; Bianchi et al., 2017), they have not focused on understanding these interactions as we do here.

\section{University-Industry Interaction Channels}

Frameworks as the quadruple helix (Carayannis \& Campbell, 2012) claim the relevance that partnership between different actors as government, civil society, industry and academic institutions have to drive innovation, something that has also been proposed for frugal innovation (Fischer et al., 2020). However, in many cases the way these partnerships occur is a black box, since there is lack of clarity on what characteristics they have and how this can impact their results. In the particular case of universities, as Fischer et al. (2020) say, few investigations have directly explored how the different mechanisms of knowledge transfer from university to society and industry can drive frugal innovation.

In this research, we explore the applicability of the framework of interaction channels between U-I to the context of frugal innovation. Historically, this framework has been used in studies of economics of science and technology, understanding the exchange of knowledge between different actors, the processes of technology transfer, the absorption capacity and their impact on innovation outcomes (Ankrah \& AL-Tabbaa, 2015; Mascarenhas et al., 2018).

By interaction channels we understand the different mechanisms used by universities to transfer knowledge and developments to industry. They can be divided in four main groups (Dutrénit \& Arza, 2015):
(1) Traditional: related to traditional teaching and research missions at universities, for example papers, and graduates themselves. The main characteristics of this type of interaction is that knowledge flows mainly from universities to industry.

2) Services: this is the case of consulting, specialised training, laboratory tests and the like. In these channels, knowledge also flows mainly from university to industry, but is motivated by commercial exchange.

3) Commercial: interaction channels with the purpose of capitalising scientific outcomes through creation of spin-off or technology licensing.

4) Bidirectional Channels: interaction channels which knowledge flows in both directions between universities and industry, for example joint research and development or participation in collaborative networks.

We claim that this approach can also be valuable in frugal innovation studies to help understand the role of the university in them by filling in two literature gaps. In the first place, recent studies point to an open research agenda in the area of diffusion and commercialisation of frugal innovations, taking into account that they have characteristics and arise in particular contexts different from those traditionally analysed by innovation studies (Hossain et al., 2016; Koerich \& Cancellier, 2019; Pisoni et al., 2018). In this sense, the U-I interaction framework could help to respond to this concern, operationalising the way in which collaborations between actors occur and their possible impacts on innovation diffusion and commercialisation.

Secondly, a major question in emerging markets, such as Latin America's, is related with the challenge about which are the best alternatives to consolidate learning processes (Brundenius et al., 2009) and connect social demands with national scientific and technological capacities. Especially, it has been argued that universities play a fundamental role in this objective of promoting inclusive technological development with social impact, being necessary to strengthen their problem-based orientation and their capacities to interact with both industry and civil society (Arocena et al., 2018; Fischer et al., 2020). In this respect, the focus of attention on frugal innovation and the contributions of U-I interaction can be an alternative to generate responses to that concern in the inclusive national innovation systems in developing countries.

\section{Methodology}

This research is part of a larger project that analyses the motivations and the U-I interaction channels preferred by 15 researchers from the National University of Colombia based in Bogotá that have participated in activities of knowledge and technology transfer to the society. Once the analysis began, it was identified that eight of these researchers worked in six innovations with frugal characteristics in the areas of health, agriculture and transport, an interesting emergent result that led us to analyse them in depth (Table 1).

These eight semi-structured interviews were transcribed and analysed with thematic content analysis (Bardin, 2011). First, familiarization 
with the data and an initial open-coding exercise began, then larger analytic categories were synthesised into three major benefits of U-I interaction in frugal innovation, and finally these results were interpreted and contrasted with previous studies.

Table 1: Research Participants

\begin{tabular}{|c|c|c|c|}
\hline $\begin{array}{l}\text { ID } \\
\text { Researcher }\end{array}$ & $\begin{array}{l}\text { Researcher } \\
\text { Area }\end{array}$ & Years of experience & Frugal Innovation Initiative \\
\hline 1 & Nursing & Between 5 and 10 & Health care programme for caregivers of patients with chronic diseases: \\
\hline 2 & Nursing & Between 5 and 10 & $\begin{array}{l}\text { It is a nursing intervention programme that innovate caring to low-income caregivers, } \\
\text { through a series of reflections, exercises and workshops, that helps them identify their po- } \\
\text { tentialities, limitations and implement actions for the well-being of the caregiver-person } \\
\text { dyad. }\end{array}$ \\
\hline & & & Device for diagnosing ophthalmic diseases: \\
\hline 3 & System Engineering & More than 20 & $\begin{array}{l}\text { It is an early-stage initiative with the purpose of building a low-cost ophthalmic device } \\
\text { that helps in the diagnosis of different diseases in rural and remote areas without the pre- } \\
\text { sence of specialised health professionals and health services. }\end{array}$ \\
\hline 6 & Agronomy & More than 20 & $\begin{array}{l}\text { Injector nozzle for precision agriculture: } \\
\text { It is a spear-shaped device that is driven into the ground for the correct dosage of pestici- } \\
\text { des used by small and medium producers in their crops, allowing a more environmentally } \\
\text { friendly production. }\end{array}$ \\
\hline & & & $\begin{array}{l}\text { Scaling-up synergetic strategies in agriculture and nutrition for food security in rural } \\
\text { communities of Colombia: }\end{array}$ \\
\hline 7 & Social Work & Between 5 and 10 & $\begin{array}{l}\text { It is a process innovation to address malnutrition in vulnerable populations, coordinating } \\
\text { institutions at the national level, with local authorities, small producers and potato mar- } \\
\text { keters to integrate guidelines and actions to link agriculture-nutrition. } \\
\text { Vehicle counting system for small and poor towns: }\end{array}$ \\
\hline
\end{tabular}

Source: Author's elaboration.

The locus of study, the National University of Colombia, was chosen because of its central role in the Colombian national innovation system. This institution is the main public university in the country; it concentrates the largest community of students and researchers, as in 2019 it had 53.304 students, 102 undergraduate programmes, 366 postgraduates and 942 research groups spread on nine cities with Bogotá being the main headquarters (Universidad Nacional de Colombia, 2020a). In fact, its relevance is not only for its size but also in terms of quality, leading the indicators of intellectual property, offering around $25 \%$ of all national doctoral programs, and publishing about $11 \%$ of scientific journals in the country (Universidad Nacional de Colombia, 2020a).

\section{Findings}

\section{The Social Role of the Colombian University and the Emergence of Frugal Innovation}

In Latin America, the public university has historically played a social role. This focus can be traced back to the first decades of the twentieth century, with the student movement of Córdoba-Argentina that began in 1918 and influenced most countries in the region (Freitas Neto, 2011). As part of a broad scope of demands that included university autonomy, co-government and student welfare, the Córdoba movement emphasized the role of the university in helping to overcome national social problems and the necessary articulation with multiple non-academic society actors (Freitas Neto, 2011). 
At the National University of Colombia, this approach is operationalised through the National Directorate of Extension, Innovation and Intellectual Property that concentrates the efforts of the extension and transfer of knowledge to other actors in society, the implementation of partnerships, the development of innovation and entrepreneurship activities aimed at solving national or international problems, and the management of intellectual property (Resolución 1221 de 2014, 2014). This organisational arrangement that begins in 2014 is particular because it places extension, innovation and intellectual property under the same roof, allowing integrality in the planning and execution of activities to impact society. One example is the annual open call of extension and social innovation initiatives, which finances initiatives aimed at solving local problems and strengthening relations with civil society, especially with vulnerable populations (Universidad Nacional de Colombia, 2020b).

This social orientation is ingrained at different levels in our study, as we identified that participating researchers wanted to give back to society and support general well-being, putting their research and development at the service of citizens:

I define myself as a civil servant, I am part of a public university, and I increasingly confirm that public universities are at the service of a country, therefore as a servant I have a specific role in the academic field, to teach, also be willing to learn, follow-up research processes and support extension projects (Researcher \#7)

In Colombia there is a historical weakness of government institutions causing great inequalities and difficulties in access to basic services, especially in remote rural areas, which have also been the main victims of the country's armed conflict. For example, by 2018, the multidimensional poverty rate that measures the percentage of people deprived of basic factors related to quality of life was 4,4\% in Bogotá, while in Vaupés, a peripheral state strongly affected by violence, it represented $59,4 \%$ of the population (DANE, 2019). Taking into account these inequalities and the economic limitations of a large part of the population, many researchers, despite not being aware of the concept of frugal innovation, decided to develop products and services with frugal characteristics trying to solve local problems:
We formulated a project that had to do with the development of low-cost devices for the acquisition of diagnostic images (...), that are generally acquired with specialised devices. The problem is that these teams are in certain medical institutions, generally located in the capitals and it is difficult to reach many areas of the country (...) in addition, ophthalmologists are also few, how to do something more massive? For example, make health brigades with low-cost portable equipment and do a kind of screening in which you apply the test to 100 people, and those five who may be at higher risk, you bring to the medical institution and apply the specialised study. (Researcher \# 3)

In fact, researchers are not only concerned with inequalities, but also with directly rewarding society for efforts in public investment in science and technology. In Colombia there is a low historical investment in research and development, for 2018 only $0,25 \%$ of GDP was dedicated to these activities (Observatorio Colombiano de Ciencia y tecnología, 2018). In this sense, researchers guided by a frugal mindset (Soni \& Krishnan, 2014) feel a great responsibility to wisely use scarce resources and have the greatest possible impact:

I, and I think that everyone who is part of the group shares that dream, that people without resources benefit (from innovation). There is a very great inequality in this country, and the people who work in the academy can help to settle at least in what corresponds to them, doing good quality things that are cheap, it is also a marketing model, something good and cheap, and it seems to me that this justifies and is a payback to what public education has given us. (Researcher \#5)

Synthesising, there is a series of elements related with the emergence of frugal innovations inside the university, as the historical social function of this institution and a scenario of inequality and scarce resources for $\mathrm{R} \& \mathrm{D}$ that promote a frugal mindset among researchers.

\section{Development of Frugal Innovation and Strengthening U-I Interaction} Once the researchers developed the first studies or pilot projects of their innovation solutions, they faced three main resource limitations, which hampered the technology transfer to society. To overcome these barriers, the participating researchers decided to explore different U-I interaction channels (Table 2), as will be described in greater detail. 
Table 2: Benefits of U-I interaction in Frugal Innovation Initiatives

\begin{tabular}{|c|c|c|c|c|}
\hline $\begin{array}{l}\text { Frugal Innovation } \\
\text { Initiatives }\end{array}$ & Stage of development & Partnership with & Channels of Interaction & Benefits \\
\hline $\begin{array}{l}\text { 1. Health care programme for } \\
\text { caregivers of patients with chro- } \\
\text { nic diseases }\end{array}$ & $\begin{array}{l}\text { In operation in multiple } \\
\text { contexts }\end{array}$ & $\begin{array}{l}\text {-Big Equipment Manufacturer } \\
\text {-Hospitals }\end{array}$ & $\begin{array}{l}\text {-Specialised training } \\
\text {-Consulting }\end{array}$ & - Innovation diffusion \\
\hline $\begin{array}{l}\text { 2. Device for diagnosing } \\
\text { ophthalmic diseases }\end{array}$ & Research & -Hospital & -Joint R\&D & - Incremental innovation \\
\hline $\begin{array}{l}\text { 3. Collagen supports for wound } \\
\text { care }\end{array}$ & $\begin{array}{l}\text { Tested in real contexts, but still } \\
\text { in the process of being made } \\
\text { viable for scale production }\end{array}$ & - Biotech company & $\begin{array}{l}\text {-Joint R\&D } \\
\text {-Technology licensing }\end{array}$ & - Scalability \\
\hline $\begin{array}{l}\text { 4. Injector nozzle for precision } \\
\text { agriculture }\end{array}$ & $\begin{array}{l}\text { Tested in real contexts, but still } \\
\text { in the process of being made } \\
\text { viable for scale production }\end{array}$ & $\begin{array}{l}\text {-Big Equipment Manufacturer } \\
\text {-Small and medium farmers }\end{array}$ & $\begin{array}{l}\text { - Consulting } \\
\text {-Technology licensing }\end{array}$ & $\begin{array}{l}\text { - Scalability } \\
\text { - Incremental innovation } \\
\text { - Innovation diffusion }\end{array}$ \\
\hline $\begin{array}{l}\text { 5. Strategies in agriculture and } \\
\text { nutrition for food security in } \\
\text { rural communities }\end{array}$ & $\begin{array}{l}\text { In operation in multiple } \\
\text { contexts }\end{array}$ & -Small farmers association & - Consulting & - Innovation diffusion \\
\hline $\begin{array}{l}\text { 6. Vehicle counting system for } \\
\text { small and poor towns }\end{array}$ & $\begin{array}{l}\text { Tested in real contexts, but still } \\
\text { in the process of being made } \\
\text { viable for scale production }\end{array}$ & $\begin{array}{l}\text {-Information technology } \\
\text { company }\end{array}$ & $\begin{array}{l}\text { - Joint R\&D } \\
\text { - Technology licensing }\end{array}$ & $\begin{array}{l}\text { - Scalability } \\
\text {-Innovation diffusion } \\
\text { - Incremental innovation }\end{array}$ \\
\hline
\end{tabular}

Source: Author's elaboration. During the study, the researchers 3, 4 and 6 were still evaluating the best alternative of licensing.

\section{Exchange Specialised Knowledge that Helps Incremental Improvements.} Researchers recognise that creating a solution that works not only in a controlled environment, as a laboratory, but also in a real context with bigger complexity is a major challenge (Researchers $3,6,8$ ). In real contexts, collaboration with industry reduces the uncertainty about technological, regulatory and environmental limitations, enabling researchers to make incremental innovations to their solutions, making their appropriation feasible. For example, in frugal innovation 2, a low-cost device for diagnosing ophthalmic diseases, the interaction with a health institution helped to create a fundamental medical and technological concept to decide the focus and main features of the prototype.

With the health institution we have been collaborating, especially in problems that are also of scientific interest to them, they have collaborated with data and with the expert medical concept (...) in medical images. It is very important that you have a good medical partner, it is essential; if not, you end up solving a problem from the engineering point of view, which suddenly does not even exist, you show it to doctors and didn't solve the problem, it's useless. (Researcher \# 3, Frugal innovation 2)

In turn, in the frugal innovation 4 , a vehicle counting system for small and poor towns, the interaction with an information technology company with experience in the public transportation sector helped the researcher to find the right match between operation conditions, regulatory framework in transport, and minimal technical specifications to build a low-cost solution without affecting the quality requirements:

In general, the researchers stay in the laboratory showing prototypes that only work here (in the university), outside you also need to take into account mundane aspects as costs, you must also have certain robustness, resist a world of environmental factors, get permissions (...) and understand that industries have very precise requirements. (Researcher \# 8, Frugal innovation 5)

It is outstanding that, of the frugal initiatives that benefited from the exchange of specialised knowledge with the industry (Frugal innovations 2, 4, 6), two of them (Frugal innovations 2 and 6) executed joint research and development, a channel of interaction that is precisely related to a two-way relationship where both parties benefit, exchanging resources and knowledge.

U-I Interaction to Access Distribution Channels and New Markets. The researchers who have led their working lives mostly in the academic world, recognise that they have little knowledge in marketing and low logistical capacities that make it difficult to promote the commercialisation and distribution of their innovation (Frugal innovations $1,4,5,6)$. In this sense, collaboration with the industry allows them to expand the scope of their frugal innovations with a less demanding learning curve and without the need for so much financial investment. Specifically, these interactions facilitate the use of distribution channels, market knowledge and the credibility that industrial partners already have. In frugal innovation 1, the interaction with a medical equipment company helped establish connections with various clinics; in frugal innovation 4 , the interaction with an agricultural equipment company would allow access to its network of clients of small and medium farmers; in frugal innovation 5, the relationships with a farmer union facilitated the adherence to the nutritional programme by multiple families and communities; and, in frugal innovation 6, the interaction with a technology company specialised in public transport allowed the dialogue and negotiation with the government of several small municipalities interested in the solution. 
A good example to better understand this argument is frugal innovation 1, a healthcare programme for caregivers of patients with chronic diseases. The leaders of this initiative conducted a consulting project co-funded by a medical equipment company to evaluate the effectiveness of the programme in the case of caregivers of patients with chronic kidney disease on peritoneal dialysis. Subsequently, the positive results of the research led the medical equipment company to support the clinics that used its Renal Therapy Services (RTS) to train their staff in the caregiver care programme, and to try to implement it in their workplaces with the accompaniment of the researchers. This way, researchers help the programme implementation in new contexts.

The managers of the institution made the decision to send a nurse to be here for a whole semester and train (in the programme) with the caregivers, and then she returned to her institute and created the caregivers' programme (...) That nurse was trained, she started doing the care programme with our accompaniment, but in a more autonomous way, then more nurses were trained and there is already a caregiver programme formally created in the institute (Researcher \#1, frugal innovation 1)

This case also demonstrates the potential of the U-I relationship to strengthen over time, going from the use of a single unidirectional interaction channel, consulting, to adding specialised training to personnel from the productive sector.

Make Scale Production Viable. Finally, a bottleneck in frugal innovations that $\mathrm{U}$-I interaction helps overcome is scalability. Initiatives 3,4 and 6, despite their high level of maturity, being protected by patents and having demonstrated their effectiveness in various environments, faced the problem of producing innovation in large volumes, since they did not have the equipment, knowledge, and resources necessary to do so.

For example, the researchers leading frugal innovation 3, collagen supports for wound and burn care, had to produce a minimum batch of units with all the quality criteria required by the authorities as a last step in obtaining permits to commercialise their solution. The problem was that although the batch was 'minimal', it represented a greater effort for the research group, so only through partnership with an industrialist who already had an adequate production plant and a qualified team they were able to manufacture it.

That (U-I Interaction) is what allowed us to finally complete the last stages of the project. We found someone who could help us in the last stage to produce, fulfil the last requirements and generate a sanitary approbation; without that we would not have been able to do it, we would have had to build a plant with all the requirements of good manufacturing practices, which is something difficult and all the time it requires... and we don't have the experience either. (Researcher \#4, frugal innovation 3)

A similar situation occurs with frugal innovations 4 and 6 , the injector nozzle for precision agriculture and a vehicle counting system for small and poor towns, which, at the time of the research, were evaluating and deciding a partnership with industrial companies that would help them in mass production. In these cases the researchers were exploring the possibility of using commercial interaction channels. Specifically, through technology licensing, an alternative that gives a third-party control over commercial exploitation, who makes its own capabilities available, avoiding that researchers invest in equipment and specialised personnel to scale production levels.

\section{Discussion}

A set of factors help to understand the emergence of multiple frugal innovations in the context of the National University of Colombia. Historically, the university and researchers have had a social vocation, which is reflected in the interaction with a variety of non-academic actors and the establishment of calls especially aimed at research and innovations with social impact. These elements are consistent with the propositions of Fischer et al. (2020), who argue that the emergence of frugal innovations in universities is enabled by an academic community oriented to relevant social problems, the creation of programmes and incentives for initiatives with social impact, in addition to the capacities to transfer knowledge to various actors in society strengthening an innovation ecosystem. Likewise, as the Latin American cases of Bayardo et al. (2018) and Busch et al. (2018) demonstrated, frugal innovation arises to serve populations and needs that the market had not been able to meet. It is also interesting that the researchers who participated in this study, although not directly familiar with the concept of frugal innovation, developed initiatives with frugal characteristics. We believe this is due to a frugal mindset that generally flourishes when people and businesses are in resource-scarce environments (Soni \& Krishnan, 2014).

Usually, innovation has been characterized as a process plagued by uncertainties of all kinds, technological, market, regulatory, social, among others. Frugal innovation is not alien to this situation. In fact, considering that it generally occurs in settings with few resources and low institutional support, it has been argued that the success of its dissemination is even more complex (Soni \& Krishnan, 2014) and that conventional theories such as Rogers' diffusion model are not necessarily suitable (Hossain et al., 2016). In this sense, it has been pointed out that there is a gap in the understanding of the role that different organisations play in the diffusion of frugal innovations (Hossain et al., 2016; Koerich \& Cancellier, 2019; Pisoni et al., 2018). Some authors mention the relevance of local companies with frugal mentality and processes which allow them to efficiently distribute the solutions on national markets, Soni and Krishnan (2014) call them domestic-corporate frugal innovators, and Hossain et al. (2016) describe this phenomenon as local diffusion pattern.

Our research suggests that part of this difficulties in diffusion can be reduced through U-I interaction. On the one hand, universities offer highly qualified human talent capacities in research and development, which, as has been mentioned in relation to the National University of Colombia case, are guided by a social orientation with the aim of giving back to society and helping to solve local problems. On the other hand, interaction with an industrial partner helps to overcome some 
innovation barriers. In line with the concept of intermediary organisation proposed by Varga and Rosca (2019), these actors, understood as public, private or non-profit organisations, not only facilitate distribution and scalability, but they also use formal and informal mechanisms to share knowledge, co-build capacities and strengthen networks that enable distribution to the base of the pyramid markets. Specifically, it was identified that bidirectional channels seem to be related to the exchange of knowledge that encourages the implementation of incremental improvements that enable the adoption of frugal innovation, and commercial channels, in particular the licensing of technologies, with scalability in the production of frugal innovation without the need of large financial investments by inventors. Likewise, as evidenced by frugal innovation 1, formal and informal U-I interactions can be strengthened over time, facilitating access to distribution channels and new viable contexts for the adoption of innovation.

Furthermore, our research has implications in the formulation of science, technology and innovation policies, especially, in those related to promoting technology transfer from universities to society. As Fischer et al. (2020) argue, to boost frugal innovation it is necessary that policymakers in emerging countries embrace a context-specific approach and select the appropriate policy instruments after carefully considering the local realities. Currently, in the case of the National University of Colombia, open calls are periodically launched to support social innovations that require interaction with civil society, initiatives that, to a certain extent, act as social incubators for projects that support the former stages of innovation development (Casasnovas \& Bruno, 2013). However, considering the environment with limited economic resources and the researchers' frugal mindset, it would be advisable to create specific incentive programmes for frugal innovation, recognising their particular needs, their efforts to reduce costs by offering good-enough solutions, and the difficulties they face in the stages of upscaling and diffusion. Otherwise, current efforts could be blurred and not meet the ultimate goal of impacting society.

In this sense, it is recommended that university technology transfer offices also have calls that promote interaction with industries, to the extent that they facilitate the exchange of specialised knowledge, access to markets and distribution channels, as well as the necessary equipment for mass production. Additionally, technology transfer offices could choose to strengthen programmes specifically aimed at the scalability of frugal innovations. One option would be through what has been called social accelerators (Casasnovas \& Bruno, 2013; Pandey et al., 2017), programmes specialised in innovations with a social impact, but with the particularity that they are focused on initiatives with a greater trajectory, helping them to have sustained growth, strengthening their work team, in addition to directly or indirectly helping in obtaining financial resources.

\section{Final considerations}

Throughout the article we have shown elements related with the emergence of frugal innovations and how their development and upscaling can benefit from U-I interaction, reducing inherent uncertainties in the innovation process, as well as some particular complexities of frugal innovation diffusion in resource-poor contexts with little institutional support. This approach gains especial relevance in emerging economies, such as Colombia and other Latin American countries, which face the challenge of consolidating learning processes (Brundenius et al., 2009) and connect social demands with national scientific and technological capacities with the purpose of promoting inclusive development (Arocena et al., 2018; Fischer et al., 2020).

The use of the theoretical framework on the U-I interaction channels was helpful to understand the different characteristics and results of partnerships in frugal innovation, such as in the case of bidirectional channels associated with knowledge exchange, and in commercial channels that lead to scalability. However, the study has some limitations: Several of the frugal innovations analysed were still in the process of maturing and establishing formal alliances with new industrial players, so it is early to be blunt about the results obtained by them. Furthermore, the study was carried out with researchers from the same, central and comparatively resourceful university, so one needs to be careful with extrapolations in other settings. Finally, we suggest as a research agenda the analysis of the point of view of companies and local organisations or communities, since they are relevant actors in these partnerships and were not included in our study. Moreover, longitudinal studies to follow-up on the evolution of types of U-I interaction channels and their effects on innovation outcomes and impact is a worthwhile research avenue to be pursued.

\section{References}

Arias, V., Julio, C.-V., Chacón, J., Vera, M., Huerfano, Y., GraterolRivas, M., Wilches-Duran, S., Rojas, J., Garicano, C., Chacín, M., \& Bermúdez, V. (2015). Impresión 3D de estructuras cardiacas: Caso de innovación frugal en sector salud. Revista Latinoamericana de Hipertensión, 10(4), 91-97.

Arocena, R., Göransson, B., \& Sutz, J. (2018). Developmental Universities in Inclusive Innovation Systems. Knowledge Democratization in the Global South. Cham, Switzerland: Palgrave McMillan.

Bardin, L. (2011). Análise de conteúdo (2a reimpressão). Edições 70.

Bayardo, M. Á. M., Zepeda, M. C., \& Delgado, D. L. (2018). De la innovación frugal a la innovación inversa: El caso del modelo farmaciadoctor en el sector salud en México. Intersticios Sociales, 8(15), 117-140.

Bhatti, Y. A., \&Ventresca, M. (2013). How can 'frugal innovation' be conceptualized? Oxford: Said Business School Working Paper Series, 1-26. Available at: http://ssrn.com/abstract=2203552.

Bianchi, C., Bianco, M., Ardanche, M., \& Schenck, M. (2017). Healthcare frugal innovation: A solving problem rationale under scarcity conditions. Technology in Society, 51, 74-80.

Busch, H.-C., Dauth, T., Fischer, L., \& Souza, M. (2018). Frugal innovation approaches to sustainable domestic energy: Two cases of solar water heating from Brazil. International Journal of Technological Learning Innovation and Development, 10(3/4), 231-257. 
Carayannis, E. G., \& Campbell, D. F. J. (2012). Mode 3 Knowledge Production in Quadruple Helix Innovation Systems. In E. G. Carayannis \& D. F. J. Campbell, Mode 3 Knowledge Production in Quadruple Helix Innovation Systems (pp. 1-63). Springer New York.

Casasnovas, G., \& Bruno, A. (2013). Scaling Social Ventures: An Exploratory Study of Social Incubators and Accelerators. Journal of Management for Global Sustainability, 1(2), 173-197.

DANE. (2019). Pobreza Multidimensional por departamentos - 2018. DANE. Retrieved from https://www.dane.gov.co/files/investigaciones/condiciones_vida/pobreza/2018/presentacion_pobreza_multidimensional_18_departamento.pdf

Dutrénit, G., \& Arza, V. (2015). Features of interactions between public research organizations and industry in Latin America: The perspective of researchers and firms. In E. Albuquerque, W. Suzigan, G. Kruss, \& K. Lee, Developing National Systems of Innovation (pp. 93-119). Cheltenham, UK: Edward Elgar Publishing.

Edwards-Schachter, M., \& Wallace, M. L. (2017). 'Shaken, but not stirred': Sixty years of defining social innovation. Technological Forecasting and Social Change, 119, 64-79.

Fischer, B., Guerrero, M., Guimón, J., \& Schaeffer, P. R. (2020). Knowledge transfer for frugal innovation: Where do entrepreneurial universities stand? Journal of Knowledge Management, ahead-ofprint(ahead-of-print).

Freitas Neto, J. A. de. (2011). A reforma universitária de Córdoba (1918): Um manifesto por uma universidade latino-americana. Revista Ensino Superior Unicamp, 3, 62-70.

Hossain, M. (2017). Mapping the frugal innovation phenomenon. Technology in Society, 51, 199-208.

Hossain, M. (2018). Frugal innovation: A review and research agenda. Journal of Cleaner Production, 182, 926-936.

Hossain, M., Simula, H., \& Halme, M. (2016). Can frugal go global? Diffusion patterns of frugal innovations. Technology in Society, 46, 132-139.

Koerich, G. V., \& Cancellier, É. L. P. D. L. (2019). Frugal Innovation: Origins, evolution and future perspectives. Cadernos EBAPE.BR, 17(4), 1079-1093.
Observatorio Colombiano de Ciencia y tecnología. (2018). Indicadores de Ciencia y Tecnología-2018.

Pandey, S., Lall, S., Pandey, S. K., \& Ahlawat, S. (2017). The Appeal of Social Accelerators: What do Social Entrepreneurs Value? Journal of Social Entrepreneurship, 8(1), 88-109.

Pansera, M. (2017). Frugalidad e innovación popular: Nuevos caminos para la sustentabilidad y la inclusión social en Ecuador. Revista Iberoamericana de Ciencia, Tecnología y Sociedad, 12(35), 131-152.

Pisoni, A., Michelini, L., \& Martignoni, G. (2018). Frugal approach to innovation: State of the art and future perspectives. Journal of Cleaner Production, 171, 107-126.

Radjou, N., \& Prabhu, J. (2019). Do Better With Less: Frugal innovation for sustainable growth. New Delhi: Penguin Random House India Private Limited.

Red Latinoamericana de Innovación Frugal. (2020, abril 20). Red Latinoamericana de Innovación Frugal. Red Latinoamericana de Innovación Frugal. Retrieved from https://redinnovacionfrugal.lat/

Soni, P., \& Krishnan, R. T. (2014). Frugal innovation: Aligning theory, practice, and public policy. Journal of Indian Business Research, 6(1), 29-47.

Tiwari, R., Kalogerakis, K., \& Herstatt, C. (2016). Frugal Innovations in the mirror of scholarly discourse: Tracing theoretical basis and antecedents. From Science to Society: Innovation and Value Creation, 1-15.

Resolución 1221 de 2014, (2014). Universidad Nacional de Colombia, Bogotá, Colombia 17 de octubre de 2014.

Universidad Nacional de Colombia. (2020a). Balance Social-2019. Universidad Nacional de Colombia. Retrieved from http://estadisticas.unal. edu.co/fileadmin/user_upload/Brochure-RC-2019_28-10-2020.pdf

Universidad Nacional de Colombia. (2020b). Innovación Social. Retrieved from http://extension.unal.edu.co/servicios/servicios-a-lacomunidad/innovacion-social/

Van der Have, R. P., \& Rubalcaba, L. (2016). Social innovation research: An emerging area of innovation studies? Research Policy, 45(9), 1923-1935.

Weyrauch, T., \& Herstatt, C. (2016). What is frugal innovation? Three defining criteria. Journal of Frugal Innovation, 2(1), 1-17. 
